\title{
Formation of Students' Methodological Culture in Vocal Training at University
}

\author{
Veronika Hasniuk 1[0000-0001-9932-0669],* Tetiana Zavadska ${ }^{2[0000-0003-4805-5142]}$
}

\author{
${ }^{1}$ Mukachevo State University, Mukachevo, Ukraine \\ ${ }^{2}$ M. P. Drahomanov National Pedagogical Universit, Kyiv, Ukraine \\ *gasnuyk69y@gmail.com
}

\begin{abstract}
The article considers the findings of the experiment that verified the level of the university student methodological culture formed in the years of university vocal training. The methodological culture of university student vocalists is considered to be one of the most important characteristics in pre-service professional training in modern higher music education. To check the level of methodological culture that pre-service music teachers have, diagnostic tools are proposed, and an appropriate system of criteria and indicators is developed. Motivational, intellectual, operational and result-corrective criteria used to develop master's student-vocalists' methodological culture are identified. The motivational criterion is characterized by professionally significant needs for a pre-service vocal teacher's professional growth. The intellectual criterion used to identify the methodological culture characterizes the level that studentsvocalists master psychological, pedagogical, professional, and methodological knowledge at. The operational criterion characterizes the students' ability to use their own profession-related vocabulary. The result-corrective criterion is related to student efficacy for self-reflection when evaluating their personal vocal teaching activity. It is proposed to identify three levels of the methodological culture including reproductive, constructive, and creative levels. Observations, surveys, practical tasks, creative independent tasks serve as the tools to identify the levels.
\end{abstract}

Keywords: modern higher music education, master's student-vocalists' methodological culture, vocal training, component, criterion, indicator, level.

\section{INTRODUCTION}

As Ukraine has joined the European education and information area, the country experienced a need in an innovative concept to modernize education, which could take into account both global and domestic educational and national traditions related to training preservice teachers in music education. According to the strategic objectives specified in the Higher Education Act of Ukraine, the National Doctrine of Education Development in Ukraine, the New Ukrainian School Concept, the ways to improve professional training of university students, the subject matter, and methodology of professional disciplines are of great importance for higher music education development. Since vocal training is an important component of professional training at art faculties, this article investigates what level of methodological culture students master when being trained as vocalists.
The concept of general teacher culture is reflected in the works of Filipchuk [1], Lola [2], Nikolaychuk [3], and others. The problem of preparing students for professional activity is presented in the studies of Davydov [4], Dubaseniuk [5], Kaidalova [6] and others. Didactics (Plaksin [7]), aesthetic culture (Garbuzenko [8]), and intellectual culture (Bondar [9], Tambovska [10]) were studied. Although many scholars researched various aspects of teacher's professional culture, quite few investigated the ways how to train preservice teacher-vocalists so that they master methodological culture and develop efficacy for implementing this knowledge in the profession.

A thorough analysis of scientific, methodological literature and practical experience shows that some contradictions exist between:

1) the expectations placed by modern education and society related to the preservice vocal teachers' level of methodological culture of and the inability of university 
graduates to independently solve innovative methodological problems;

2) the need to introduce modern methods and technologies into university innovative programs, and conservatism of lecturers who train preservice teachers at institutions of higher music education.

Resolving these contradictions requires changes in vocal training of preservice teachers at universities, the search for new methods, forms and means of teaching, Internet resources and more.

\section{LITERATURE REVIEW}

In the scientific and pedagogical community, the phenomenon of teacher's methodological culture is interpreted ambiguously. Karachevtseva considers methodological culture a systemic individual feature that characterise the preservice teacher, his /her methodological activity and thinking. It is a process when a preservice teacher develops self-determination followed by self-development and self-improvement. In this sense, methodological culture indicates preservice teacher's methodological efficacy, identifies the level of methodological thinking, personal development, and ability to apply psychological, pedagogical and professional competence to become methodologically competent [[11][12]. Plekhanov refers to methodological culture as a teacher's socio-professional characteristic, which enhances teacher's professional activity and the ability to use pedagogical tools in teaching. Methodological culture creates and assimilates new pedagogical values and technologies.. The new trends in teaching and learning in higher education institutions due to the transition to online teaching caused by the COVID 19 were discussed by many scholars $[14 ; 15 ; 16 ; 17]$.

The meaning of a teacher's methodological culture suggests that it values domestic and foreign experience in vocal teaching, competence in the theory and methodology of teaching vocal, vocal performance skills, creative self-realization in vocal and pedagogical activity. Methodological culture characterizes the ways master's students apply acquired theoretical knowledge, skills, and experience of applying teaching methods to realize the potential in the future profession.

\section{METHODOLOGY}

The experiment was conducted in two different stages. First, the hypothesis was constructed; master's students-vocalists at designated universities in Ukraine were diagnosed for their initial level of the methodological culture. Then, methodology to improve their methodological culture was used in the experimental group. Finally, after a semester of studies, master's students were surveyed to identify any changes in the level of their efficacy to teach vocal.
The participants in the study were full time master's students including:

- 1 first-year master's student and 5 second-year master's students from pedagogical faculty at Mukachevo State University (6 people total);

- 3 first-year master's students and 3 second-year master's students from the Faculty of Culture and Arts at Lviv National University (6 people total);

- 2 first-year master's students and 2 second-year master's students majoring in 014 Secondary Education (Music Art) and 4 first-year master's students and 4 second-year master's students majoring in 025 Musical Art from Anatoly Avdievsky Faculty of Arts at M. P. Drahomanov National Pedagogical University (totaled 12 master's students).

Thus, the sample of the experimental research was 24 students. All participants were divided into control group (hereinafter-CG) of 10 students, accounting for $41.67 \%$, and an experimental group (hereinafter - EG), which included 14 students, making up $58.33 \%$ of respondents.

\section{DATA COLLECTION AND DATA ANALYSIS}

Data were collected through conversations, direct and indirect observation, followed by analysis of preservice teachers' teaching. Pedagogical experiment was used to obtain reliable data on how methodological culture of master's students-vocalists have been formed. Since the observational experiment involved determining qualitative and quantitative methods of processing the obtained data, the method of mathematical processing was used to analyze the empirical data of diagnostic results, the methods of comparative analysis were used to test research hypothesis that was developed during the experimental study.

\section{RESULTS AND DISCUSSION}

To identify the level of the methodological culture that master's students acquire through vocal training, we analysed the educational and professional curriculum for the 025 Music Art major. The analysis of the core and elective components of the university educational and professional curriculum, used to train preservice vocal teachers, helped to identify those courses that develop professional knowledge, skills and abilities for vocal and pedagogical work at art higher education institutions, as well as the availability of various types of pedagogical practice, which also contribute to the application of the methodological knowledge, and the development of professional skills and abilities.

It is important to note that we analysed only those disciplines that were relevant for our study. The methodological culture of master's students-vocalists is developed through a systematic study of such core 
disciplines that belong to the cycle of professionally oriented training including Qualification Seminar: Voice Production, Methods of Qualification Teaching: Voice Production, Theory and Teaching Methods Applied to Teach Qualification Course (Voice Staging) at the Higher Education Institution, Pedagogical Practice and Assistant Practice.

The diagnostic stage of the experiment was carried out according to the program, and took into account the natural conditions in which vocal training of preservice vocal teachers takes place. Quantitative and qualitative indicators that prove the level of master's students' methodological culture mastered through the vocal training were determined with the help of certain methods.

Thus, the motivational component as part of the vocal students' methodological culture includes methodological orientation, and interest in the vocal training methods and pedagogy used to apply those methods. The methods that diagnose individual professional efficacy (adapted method of B. Bass) and methods to identify individual motivation to acquire methodological culture were used. The measurements showed that $17.14 \%$ of respondents were at the creative level of interest. This figure was followed by $26.78 \%$ of respondents who were at a constructive level while $56.07 \%$ were at the reproductive level (Table 1).

The cognitive component of the master's students' methodological culture includes understanding the professional language, the knowledge of the theory of the sound and methods of voice production. The level of the cognitive component was determined by using questionnaires that identify the level of professional language, methodological knowledge of preservice vocal teachers. The written diagnostic work was used to identify the quality of student knowledge of the methods of vocal training. CG and EG vocal students were asked to answer the questions in the questionnaire, in order to examine the students' level of understanding the professional language, as well as to identify how they master the vocal pedagogy. Students were asked to write a written diagnostic paper to identify the quality of knowledge of the theory and methods of voice production. The written work provided answers to questions related to the theoretical and methodological foundations of art education.

The results given in Table 2 evidence that in general, both CG vocal students and EG vocal students lack the appropriate knowledge of the theory and methods of voice production to provide teaching vocal at school, college, or university. Only $20 \%$ of respondents showed a creative level and $34.28 \%$ of respondents had a constructive level, while the percentage of respondents with a reproductive level was quite high $(45.72 \%)$.

Thus, based on the results of questionnaires and written diagnostic work, it is possible to state that the established traditional approaches used to develop methodological culture of the preservice teachers do not meet the new requirements; they are not efficient enough to provide students with the necessary level of efficacy for future vocal and pedagogical activities.

In order to identify the technological component of the master's students' methodological culture in the process of vocal training, the operational criterion was determined. It included several indicators: the qualification in understanding vocal and pedagogical repertoire, ability to interpret and perform music pieces, skills to analyse artistic and pedagogical value of vocal work.

To diagnose the level of the technological component, master's students were observed during their pedagogical practice. A questionnaire was also administered to identify the level of preservice vocal teachers' professional language and methodological knowledge.

Table 1. Master's students' methodological culture acquired through vocal training (motivational component)

\begin{tabular}{|c|c|c|c|c|c|}
\hline \multirow[t]{2}{*}{ Level } & \multicolumn{2}{|c|}{$\begin{array}{c}\text { Master's students' } \\
\text { methodological orientation }\end{array}$} & \multicolumn{2}{|c|}{$\begin{array}{l}\text { Master's students' interest in } \\
\text { the vocal training methods and } \\
\text { pedagogy used to apply those } \\
\text { methods }\end{array}$} & \multirow{2}{*}{ 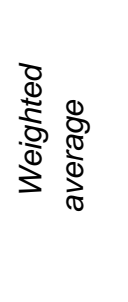 } \\
\hline & $\begin{array}{c}\mathrm{CG} \\
10 \text { students }\end{array}$ & $\begin{array}{c}\mathrm{EG} \\
14 \text { students }\end{array}$ & $\begin{array}{c}\text { CG } \\
10 \text { students }\end{array}$ & $\begin{array}{c}\text { EG } \\
14 \text { students }\end{array}$ & \\
\hline Creative & $2(20 \%)$ & $2(14,28 \%)$ & $2(20 \%)$ & $2(14,28 \%)$ & 17,14 \\
\hline Constructive & $3(30 \%)$ & $4(28,57 \%)$ & $2(20 \%)$ & $4(28,57 \%)$ & 26,78 \\
\hline Reproductive & $5(50 \%)$ & $8(57,14 \%)$ & $6(60 \%)$ & $8(57,14 \%)$ & 56,07 \\
\hline
\end{tabular}


Table 2. Master's students' methodological culture acquired through vocal training (cognitive component)

\begin{tabular}{|c|c|c|c|c|c|}
\hline \multirow{2}{*}{ Level } & \multicolumn{2}{|c|}{$\begin{array}{l}\text { Understanding of professional } \\
\text { language }\end{array}$} & \multicolumn{2}{|c|}{$\begin{array}{l}\text { Sufficiency of students' knowledge } \\
\text { of the theory and methods of voice } \\
\text { production }\end{array}$} & \multirow{2}{*}{ 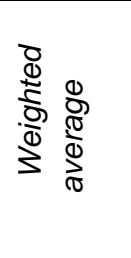 } \\
\hline & $\begin{array}{c}\text { CG } \\
10 \text { students }\end{array}$ & $\begin{array}{c}\text { EG } \\
14 \text { students }\end{array}$ & $\begin{array}{c}\text { CG } \\
10 \text { students }\end{array}$ & $\begin{array}{c}\text { EG } \\
14 \text { students }\end{array}$ & \\
\hline Creative & $2(20 \%)$ & $4(28,57 \%)$ & $1(10 \%)$ & $3(21,43 \%)$ & 20 \\
\hline Constructive & $4(40 \%)$ & $4(28,57 \%)$ & $4(40 \%)$ & $4(28,57 \%)$ & 34,28 \\
\hline Reproductive & $4(40 \%)$ & $6(42,86 \%)$ & $5(50 \%)$ & $7(50 \%)$ & 45,72 \\
\hline
\end{tabular}

The findings illustrated that only $17.38 \%$ of respondents are qualified in the vocal and pedagogical repertoire, have the skills of artistic and pedagogical analysis of the vocal work and are able to perform interpretations of musical works; $30 \%$ of respondents could understand the vocal and pedagogical repertoire, partially carried out artistic and pedagogical analysis of the vocal work and interpreted music pieces; $52.62 \%$ of respondents demonstrated an insufficient understanding of the vocal and pedagogical repertoire, partially performed artistic and pedagogical analysis of the vocal work and were not able to interpret music pieces during the performance (Table 3).

The control-correcting component of the master's students' methodological culture was determined by the analysis of pedagogical practice and performances during the evaluation sessions. This helped to understand if master's students can adequately self-reflect on the results of vocal and pedagogical activities, as well as to assess the course and outcome of vocal performance and their ability to analyse technical and interpretive shortcomings of vocal performance and vocal education.

Table 3. Master's students' methodological culture acquired through vocal training (operational component)

\begin{tabular}{|c|c|c|c|c|c|c|c|}
\hline \multirow{2}{*}{ Level } & \multicolumn{2}{|c|}{$\begin{array}{c}\text { Qualified understanding } \\
\text { of the vocal and pedagogical } \\
\text { repertoire }\end{array}$} & \multicolumn{2}{|c|}{$\begin{array}{l}\text { Ability to interpret and } \\
\text { perform music pieces }\end{array}$} & \multicolumn{2}{|c|}{$\begin{array}{l}\text { Skills of artistic and } \\
\text { pedagogical analysis of } \\
\text { a vocal work }\end{array}$} & \multirow{2}{*}{ 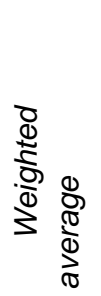 } \\
\hline & $\begin{array}{c}\text { CG } \\
10 \text { students }\end{array}$ & $\begin{array}{r}\text { EG } \\
14 \\
\text { students }\end{array}$ & $\begin{array}{c}\text { CG } \\
10 \\
\text { students } 6\end{array}$ & $\begin{array}{r}\mathrm{EG} \\
14 \\
\text { students }\end{array}$ & $\begin{array}{r}\mathrm{CG} \\
10 \\
\text { students }\end{array}$ & $\begin{array}{r}\mathrm{EG} \\
14 \\
\text { students }\end{array}$ & \\
\hline Creative & 2 (20\%) & $\begin{array}{c}3 \\
(21,43 \%)\end{array}$ & $\begin{array}{c}1 \\
(10 \%)\end{array}$ & $\begin{array}{c}3 \\
(21,43 \%)\end{array}$ & $\begin{array}{c}1 \\
(10 \%)\end{array}$ & $\begin{array}{c}3 \\
(21,43 \%)\end{array}$ & $\begin{array}{l}17 \\
38\end{array}$ \\
\hline Constructive & $3(30 \%)$ & $\begin{array}{c}4 \\
(28,57 \%)\end{array}$ & $3(30 \%)$ & $\begin{array}{c}4 \\
(28,57 \%)\end{array}$ & $\begin{array}{c}2 \\
(20 \%)\end{array}$ & $\begin{array}{c}6 \\
(42,86 \%)\end{array}$ & 30 \\
\hline Reproductive & $5(50 \%)$ & $\begin{array}{c}7 \\
(50 \%)\end{array}$ & $\begin{array}{c}6 \\
(60 \%)\end{array}$ & $\begin{array}{c}7 \\
(50 \%)\end{array}$ & $\begin{array}{c}7 \\
(70 \%)\end{array}$ & $\begin{array}{c}5 \\
(35,71 \%)\end{array}$ & $\begin{array}{l}52, \\
62\end{array}$ \\
\hline
\end{tabular}

After the control and corrective component was analysed, it evidenced that $12.85 \%$ of respondents could adequately self-evaluate the results of vocal and pedagogical activities, were able to assess the course and outcomes of vocal and performance activities, and could analyse technical and interpretive shortcomings of vocal and / vocal and pedagogical activities (creative level). This number was followed by those with a constructive level, accounting for $22.38 \%$; and $64.76 \%$ of master's students were qualified with a reproductive level (Table 4). 
Table 4. Master's students' methodological culture acquired through vocal training (control and corrective component)

\begin{tabular}{|c|c|c|c|c|c|c|c|}
\hline \multirow[t]{2}{*}{ Level } & \multicolumn{2}{|c|}{$\begin{array}{l}\text { Ability to self-evaluate } \\
\text { vocal pedagogical activity }\end{array}$} & \multicolumn{2}{|c|}{$\begin{array}{c}\text { Ability to evaluate the } \\
\text { process and results of } \\
\text { vocal and performance } \\
\text { activities }\end{array}$} & \multicolumn{2}{|c|}{$\begin{array}{l}\text { Ability to analyze } \\
\text { technical and interpretation } \\
\text { failures in the vocal and } \\
\text { performing and vocal } \\
\text { teaching activities }\end{array}$} & \multirow[t]{2}{*}{ 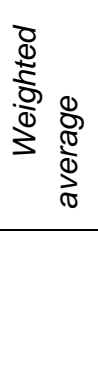 } \\
\hline & $\begin{array}{r}\mathrm{CG} \\
10 \\
\text { students }\end{array}$ & $\begin{array}{r}\mathrm{EG} \\
14 \\
\text { students }\end{array}$ & $\begin{array}{c}\mathrm{CG} \\
10 \\
\text { students }\end{array}$ & $\begin{array}{r}\mathrm{EG} \\
14 \\
\text { students }\end{array}$ & $\begin{array}{c}\mathrm{CG} \\
10 \\
\text { students }\end{array}$ & $\begin{array}{r}\mathrm{EG} \\
14 \\
\text { students }\end{array}$ & \\
\hline Creative & $\begin{array}{c}1 \\
(10 \%)\end{array}$ & $\begin{array}{c}3 \\
(21,43 \%)\end{array}$ & $1(10 \%)$ & $\begin{array}{c}3 \\
(21,43 \%)\end{array}$ & $0(0 \%)$ & $\begin{array}{c}2 \\
(14,29 \%)\end{array}$ & $\begin{array}{l}12, \\
85\end{array}$ \\
\hline Constructive & $\begin{array}{c}3 \\
(30 \%)\end{array}$ & $\begin{array}{c}3 \\
(21,43 \%)\end{array}$ & $2(20 \%)$ & $\begin{array}{c}3 \\
(21,43 \%)\end{array}$ & $2(20 \%)$ & $\begin{array}{c}3 \\
(21,43 \%)\end{array}$ & $\begin{array}{l}22, \\
38\end{array}$ \\
\hline Reproductive & $\begin{array}{c}6 \\
(60 \%)\end{array}$ & $\begin{array}{c}8 \\
(57,14 \%)\end{array}$ & $7(70 \%)$ & $\begin{array}{c}8 \\
(57,14 \%)\end{array}$ & $8(80 \%)$ & $\begin{array}{l}9(64,28 \\
\%)\end{array}$ & $\begin{array}{l}64, \\
76\end{array}$ \\
\hline
\end{tabular}

Thus, the detailed analysis of the participants' work at the observational stage of the experiment allowed us to outline the idea of the phenomenon under study and to implement a differentiated approach to determining the initial level of master's students' methodological culture development through the vocal training.

To identify the quantitative characteristics of the preservice vocal teacher's methodological culture for each criterion, the following equation was used:

$$
\mathrm{MC}=\frac{\mathbf{P 1}+\mathbf{P 2}}{\mathbf{N P}}
$$

where: $\mathrm{MC}$ is quantitative level of the methodological culture according to one of the criteria (motivational; information-analytical; operational; and effectcorrective);

P1 is the initial level of master's students' understanding of methodology by the motivational criterion;

P2 is initial level of master's students' interest in the methods of vocal education by the motivational criterion;

NP is the number of indicators of the motivational criterion.

That is, the equation to identify the level of the first criterion of methodological culture, motivational, looked like this:

$$
\mathrm{MC}_{1}=\frac{\mathbf{P 1}+\mathbf{P 2}}{2}
$$

where: P1 is the initial level of methodological orientation of the master's students; P2 is interest in the methods of vocal training; 2 is the number of indicators of the motivating criterion.
Similar equation was used to identify the level of the other criteria of vocal master's students' methodological culture.

Thus, the first stage of the experiment showed that most master's students have a reproductive level of methodological culture accounting for $54.79 \%$; 28.365 of respondents had a constructive level, while the smallest number of respondents $16.84 \%$ had a creative level (Table 5).

At the formative stage of the research the progressive methods to form the master's students' methodological culture during their vocal training was introduced. The new methodology was targeted at improving the content, forms, and methods. At the formative stage of the experiment the following methods were used: methodological commenting, live illustration by voice, method of audio fixation, active observation how inservice faculty members were teaching the vocal class, and methodological analysis of the vocal material. There were several techniques including: a) independent studies in Qualification Seminar classes, (independent study of a simple piece with an accompanist, preparation of vocal illustrations of the piece with an annotation); analysis of problems related to vocal-performing and vocal-pedagogical process; c) the awareness of the professional activity model of a vocal teacher. During the observation practice (so-called passive practice) master's students kept a trainee's diary, where they recorded the tasks and methods used to develop students' singing. They also developed an electronic methodological portfolio of the preservice vocal teacher. 
In order to determine the efficiency of the proposed methods that could be used to develop the vocal master's students' methodological culture, each of the component of the methodological culture was diagnosed and then the findings were compared with the data of the preexperimental stage. A comparative analysis of the data in the experimental and control groups allowed us to note that the positive changes were more intense in the experimental group. Experiencing traditional teaching in the control group, the master's students in the control group also managed to improve the level of their methodological culture, however, insignificantly (Table 6).

Table 5. Qualitative characteristics of the vocal master's students' methodological culture at the pre-experimental stage

\begin{tabular}{|c|c|c|c|c|c|}
\hline \multirow{2}{*}{ Level } & \multicolumn{4}{|c|}{ Criteria } & $\begin{array}{c}\text { Weighted } \\
\text { average of the } \\
\text { MC }\end{array}$ \\
\cline { 2 - 5 } & Motivational & $\begin{array}{c}\text { Information } \\
\text { and analytical }\end{array}$ & Operational & $\begin{array}{c}\text { Effect and } \\
\text { correctional }\end{array}$ & 16,84 \\
\hline Creative & $17,14 \%$ & $20 \%$ & $17,38 \%$ & $12,85 \%$ & 28,36 \\
\hline Constructive & $26,78 \%$ & $34,28 \%$ & $30 \%$ & $22,38 \%$ & 54,79 \\
\hline Reproductive & $56,07 \%$ & $45,72 \%$ & $52,62 \%$ & $64,76 \%$ & \\
\hline
\end{tabular}

Table 6. Dynamics that explains the level of the methodological culture that masters' students-vocalists in the experimental and control groups had during the 3rd stage of formative experiment

\begin{tabular}{|c|c|c|}
\hline Levels & CG & EG \\
\hline Creative & $10 \%$ & $33,33 \%$ \\
\hline Constructive & $43,33 \%$ & $45,24 \%$ \\
\hline Reproductive & $46,67 \%$ & $21,43 \%$ \\
\hline
\end{tabular}

\section{CONCLUSION}

Thus, analysing the research findings it is possible to conclude that the methods used to develop methodological culture through the vocal training given to masters' students at university produced noticeable changes in the participants' knowledge of the subject matter, and the goals and content of vocal training in general. At the beginning of the experiment, master's students defined the purpose of their studies as a process of mastering a certain amount of educational content of professional knowledge and skills. Such approach narrows down the concept of the study goals. When the experimental technique aiming at developing methodological culture was applied, it helped students to reconsider and reinterpret the semantic characteristics of the specified problem. Students realized that becoming a qualified professional in music requires meaningful conscious analysis of prospective professional activities, understanding of its methodological systems, based on mastering communicative, representative and expressive skills that form the basis of their methodological culture.

\section{REFERENCES}

[1] Filipchuk, H.H. (2012), Filosofiia ekolohichnoi osvity staloho rozvytku, monohrafiia, Zelena Bukovyna, Chernivtsi, Ukraina.

[2] Lola, V.H. (2013), Tekhnolohichna kul'tura vchytelia: sutnist' i model' formuvannia LANDONKhKhI, Donets'k, Ukraina.

[3] Nikolajchuk, T.A. (2014), "Metodychna kul'tura peredumova vynyknennia novykh idej u pedahohichnij nautsi ta praktytsi", Rozvytok metodychnoi kul'tury pedahoha iak napriam vyperedzhuval'noi osvity: tematychnyj zbirnyk prats', 23 p.

[4] Davydov, M.A. (2004), Teoretychni osnovy formuvannia vykonavs'koi majsternosti baianista (akordeonista), Muzychna Ukraina, Kyiv, Ukraina.

[5] Dubaseniuk, O. A. (2009), Profesijna pedahohichna osvita: innovatsijni tekhnolohii ta metodyky, monohrafiia, Vyd-vo ZhDU im. I. Franka, Zhytomyr, Ukraina.

[6] Kajdalova, L. H. (2011), “Profesijna diial'nist' iak osnova pidhotovky majbutnikh fakhivtsiv $u$ 
vyschykh navchal'nykh zakladakh", Problemy inzhenerno-pedahohichnoi osvity. vol. 30-31, pp. 152-158.

[7] Plaksin, A.A. (2015), "Dydaktychna kul'tura iak naukovyj fenomen, joho struktura ta sutnisni kharakterystyky", Osvitolohiia, vol. 4, pp. 126130 .

[8] Harbuzenko, L.V. (2015), "Systema navchal'nykh zavdan' dlia formuvannia khudozhn'o-estetychnoi kompetentnosti majbutnikh uchyteliv obrazotvorchoho mystetstva", Problemy pidhotovky suchasnoho vchytelia, vol.12, pp. 137143.

[9] Bondar, M.V. (2009), "Intelektual'na kul'tura osobystosti: istoryko-definityvnyj analiz", Novi tekhnolohii navchannia, Zbirnyk naukovykh prats' "Dukhovno-moral'ne vykhovannia profesionalizm osobystosti $\mathrm{v}$ suchasnykh umovakh», spets. vol. 60, Instytut innovatsijnykh tekhnolohij i zmistu osvity MON Ukrainy, Akademiia mizhnarodnoho spivrobitnytstva $\mathrm{Z}$ kreatyvnoi pedahohiky, Kyiv-Vinnytsia, pp. 45-51.

[10] Tambovs'ka, K.V. (2014), “Intelektual'na kul'tura j intelektual'nyj rozvytok fakhivtsia iak stratehichna meta iakisnoi pedahohichnoi osvity", Pedahohika vyschoi ta seredn'oi shkoly, vol. 42, pp. 208-213.

[11] Karachevtseva, A. P. (2001), "Metodycheskaia kul'tura kak dydaktycheskoe uslovye professyonal'noho obrazovanyia uchytelia", Materyaly Vserossyjskoj nauchno-praktycheskoj konferentsyy, Tvorcheskaia samorealyzatsyia lychnosty v kontekste professyonal'noj pedahohycheskoj kul'tury, Yzd-vo BelHU, Belhorod, Rossyia, pp. 105-107.
[12] Kozii, O. Ulianova, V. Bilostotska, O. Kachmar, O. Bakhmat, N. Prokopchuk, V. and Komarovska, O. (2020), "Experience in Developing Imaginative and Intonational Competencies in Future Music Teachers", Revista Romaneascapentru Educatie Multidimensionala, vol. 12(4), pp. 16-37. DOI: https://doi.org/10.18662/rrem/12.4/331.

[13] Hrytsaj, N.B. (2012), "Metodychna kul'tura iak vazhlyvyj komponent systemy metodychnoi pidhotovky majbutn'oho vchytelia biolohii", Pedahohichni nauky: teoriia, istoriia, innovatsijni tekhnolohii, vol. 7 (25), pp. 3-9.

[14] Amjad, M. and Linda, N.J. (2020), “A Web Based Automated Tool for Course Teacher Evaluation System (TTE)", International Journal of Education and Management Engineering, vol. 10, no. 2, pp.11-19. DOI: 10.5815/ijeme.2020.02.02

[15] Ahuja, S. Kaur, P. and Panda, S.N. (2019), "Identification of Influencing Factors for Enhancing Online Learning Usage Model: Evidence from an Indian University", International Journal of Education and Management Engineering, vol. 9, no. 2, pp. 15-24. DOI 10.5815/ijeme.2019.02.02

[16] Hassan, M.M. and Mirza T. (2021), "The Digital Literacy in Teachers of the Schools of Rajouri (J\&K)-India: Teachers Perspective”, International Journal of Education and Management Engineering, vol. 11, no. 1, pp. 28-40. DOI: 10.5815/ijeme.2021.01.04

[17] Hussain, M.W. Mirza, T. and Hassan, M.M. (2020), "Impact of COVID-19 Pandemic on the Human Behavior", International Journal of Education and Management Engineering, vol. 10, no. 5, pp. 35-61. DOI:10.5815/ijeme.2020.05.05 